\author{
Magdalena KUŹMA, MA \\ Faculty of Economics and Management, University of Bialystok \\ e-mail: m.kuzma@uwb.edu.pl \\ ORCID: 0000-0001-8727-6955
}

DOI: $10.15290 /$ oes.2018.04.94.08

\title{
FINANCIAL MANAGEMENT OF STATE FORESTS NATIONAL FOREST HOLDING IN RELATION TO CHALLENGES OF SUSTAINABLE DEVELOPMENT OF FORESTRY
}

\begin{abstract}
Summary
Goal is to systemise knowledge about the rules and basic elements of financial management of the State Forests as an entity responsible for the sustainable development of forestry in Poland.

Research methodology used in the study is analysis of the literature related to financial management of enterprises in the forestry sector, especially in the SFNFH, as well as sustainable forest economy. The literature review allows the author to examine the general rules, aims and elements of financial management of the State Forests. The determinants influencing the form of financial management of this entity are also indicated.

Score: The research confirms that the financial management of the State Forests is influenced by numerous factors resulting from the specific nature of the forest industry. On one hand, there is a necessity to take into account the economic efficiency of conducted operations, as well as the need for maintaining the financial independence of all the SFNFH's organisational units. On the other hand, any initiated activities should comply with environmental requirements and the social needs of society.
\end{abstract}

Key words: State Forests, financial management, sustainable development

JEL classification: L320, Q230

\section{Introduction}

Forests fulfill multiple roles within the economy. Not only are they a source of timber, but they also perform non-economic functions, e.g. support tourism and recreation in forested areas as well as provide aesthetic benefits [Płotkowski, 2008, p. 264]. Appropriate management of forested areas requires, therefore, simultaneous consideration of economic, ecological and social determinants. Only then is it possible to maintain balance between these three areas and to ensure sustainable development of forested regions.

The broad range of benefits provided by forests makes them a public good and, in many countries, they are administered by public authorities. This is the case, for 
instance, in European Union countries, ${ }^{1}$ where the combined share of public ownership of forests amounts to approximately 40\% [Agriculture ..., 2017, p. 114]. The approach to forest management in these states as well as their results, including financial results, impact the development of the entire forestry sector of the EU [Liubachyna et al., 2017, p. 162].

The State Forests National Forest Holding (SFNFH) of Poland is one of the largest national forest holdings in Europe. ${ }^{2}$ It manages forests belonging to the State Treasury and represents it in the field of property management. As part of that, it takes care of forest management, manages land and other immovable and movable assets related to forestry, as well as inventories and assesses the value of assets belonging to the State Treasury. The area of lands managed by the State Forests is 7.3 million hectares, i.e. $77.4 \%$ of the entire amount of forests in Poland [Local Data Bank, 2017], and the entity manages approximately $25 \%$ of the land area of the entire country.

The responsibility of the State Forests is to conduct sustainable and multifunctional management of forests. This means that its operations are conducted in a manner which ensures that the present needs of society are not fulfilled at the expense of the ability to meet the needs of future generations [Sadowska, Lulek, 2018, p. 104]. To achieve that, they must reconcile three perspectives: economic, social, and environmental [Misztal, 2018, pp. 27-29]. Therefore, its operations are directed at maintaining a balance between economic interests and ecological requirements, as well as the social needs of citizens [Płotkowski, 2008, p. 253]. Managing forests in a sustainable and multifunctional manner is a long-term process and requires analysis of the financial foundations of the State Forests, with consideration for the economic efficiency of the undertaken activities. Economically efficient measures should ensure the fulfillment of social, ecological, economic, cultural, and spiritual needs of the current and future generations. However, the specific character of these activities is that they seem efficient over shorter periods of time but may prove inefficient in the long-term [Gospodarka finansowa ..., 2015].

Financial management of the SFNFH varies significantly from the financial management of other economic entities, because of the specific conditions necessary for multifunctional and sustainable forestry. The aim of this paper is to systematise knowledge about the rules and basic elements of financial management of the State Forests as an entity responsible for the sustainable development of forestry in

1 Among the EU countries, Poland is second in terms of both the area of publicly owned forests and their percentage within the total of these resources in a given country. In regard to the first criterion, Poland is only surpassed by Spain, whose area of public forests is 8.1 million hectares, with a share of public ownership of $29.2 \%$. A greater share of public forests occurs only in Bulgaria and amounts to $87.9 \%$, or approximately 3.4 million hectares [Agriculture ..., 2017, p. 114].

2 The State Forests is an organisational unit which is not considered a legal personality and operates on the basis of the Act of September 28th of 1991 on forests and executive regulations to that Act [Act, 1991]. Appropriate legal regulations gave SFNFH legal enforceability as well as legal and actual capacity; they also define its operational and property related range [Szczypa, 2016, pp. 176177]. 
Poland. The analysed problem seems to be relevant and interesting due to the specific nature of the industry in which the SFNFH operates, and also because of its references to research on sustainable development. The layout and content of this publication have been constructed to comply with the adopted purpose. The main method used in the paper is analysis of the literature related to financial management of enterprises in forestry sector, as well as sustainable forest economy.

\section{Rules of financial management of state forests national forest holding}

The financial management of an enterprise should be a continuous and appropriately organised process involving earning revenues and income as well as making expenditures from the available financial resources. It covers all the activities related to financial operations connected with the preparation, actual realisation, recording, and analysis of financial phenomena [Szyszko, Szczepański, 2003, pp. 17-20]. Financial management of an economic entity is influenced by various factors which, among others, include: type of organisational and legal framework of business activity, its ownership structure, adopted strategy for development, applicable legal constraints, size or type of activity. These determinants also impact the financial management of the State Forests, which differs considerably from the financial management of other economic entities, such as institutions from the public finance sector, state-owned enterprises, or commercial entities. This is a result of the specific nature of the SFNFH's operations connected with forest management involving, but not limited to [Buraczewski, 2013, p. 21]:

1. strong dependence on natural conditions,

2. lack of close correlation between undertaken efforts and their effect, which leads to disproportions between expenditures on production and the value of obtained timber or other forest produce,

3. long period of time between an expenditure and its effect, creating a situation where the time of wood production does not coincide with accounting periods,

4. difficult assessment of forest assets which are the means of production as well as the final product,

5. the need to equalise financial abilities of individual organisational units on account of the diversity in their natural and economic conditions,

6. difficulty in describing relations between generated revenues and the realisation of multidimensional functions by forests, especially those which are noneconomic in nature,

7. difficulty in assessing the value of the non-economic (social) functions of forests.

Financial management of the SFNFH covers all the activities connected with the financial operations in three areas. The first one concerns the preparation of financial phenomena which aid processes desired by the SFNFH. This stage encompasses forecasting, anticipating, and planning of these operations. An example of such an 
activity is the creation of a long-term forest management plan, consistent with the concept of sustainable development [Bugno-Pogoda, Durak, 2018, pp. 10-11]. This document makes it possible to implement sustainable forest economy, thanks to reconciling environmental considerations with economic goals. To achieve this purpose, the SFNFH develops annual financial and economic plans of individual organisational units on the basis of this plan [Buraczewski, 2001, pp. 90-91]. The second area covers the realisation of financial operations consisting in collecting, division, and spending of financial resources [Szewczuk, 2006, pp. 349-350] by the State Forests. The last area encompasses recording and assessment of the implemented financial phenomena. The SFNFH is obliged to prepare reports mandated by law, including the Accounting Act or the Forest Act. One type of such reports is the financial and economic report and financial statement which must be submitted to the owner every year. On the basis of the prepared reports, appropriate entities assess the economic effects of conducted activities, including the rationality of financial management. Conclusions from that assessment are used to make decisions about future financial operations [Buraczewski, 2001, pp. 96-102].

The goal of financial management of the SFNFH is to define the financial requirements necessary to cover the expenditures of individual units during particular accounting periods. Their amounts are determined on the basis of information describing planned commissioned tasks and objective tasks. The former are finances from public resources, while the latter are funded from financial resources obtained as a result of conducted operations. Financial management of the SFNFH also aims to identify the conditions which are essential for the self-financing of its operations, and creating the financial surplus to swell its resources. Additionally, the financial management of the SFNFH is oriented at initiating behaviours designed to save and those leading to raising the effectiveness of conducted activities [Buraczewski, 2013, p. 247].

To achieve the goals of financial management it is necessary to conduct it in accordance with certain rules. Most importantly, the activity of the SFNFH is based on financial independence, which means that the costs of its operations are covered from its own revenues. Therefore, the ability to realise individual tasks related to forest management also depends on its ability to generate revenues (mainly through the sale of wood), as well as the optimisation of expenditures made [Gospodarka finansowa ..., 2015]. The State Forests also divides its activities into [Act, 1994]:

1. administrative operations,

2. economic operations including:

- core activity covering the protection, propagation and management of forests, maintenance and expansion of plantings and forest related resources as well as the acquisition (with the exclusion of purchasing) and sale of unprocessed wood,

- sideline business encompassing animal management, acquisition (excluding the purchasing) of spruce, resin, tree bark, needles, fatwood, animals and forest fruit, and the sale of these products in their unprocessed state, 
3. additional operations involving production or services connected with forest management.

Administrative and core activities are subject to the mechanism of economising and tasks within these areas are realised independently of the amounts of generated revenues or costs. On the other hand, sideline and additional operations can be carried out only and exclusively in situations when expenditures made to conduct them will not exceed the revenues generated within that area [Buraczewski, 2013, p. 247].

The above activities allow the SFNFH to fulfill - with the use of forest resources - their functions in compliance with the concept of sustainable development. The areas of activity of this entity divided into economic, social and environmental purposes are presented in table 1.

TABLE 1

Examples of economic, social and environmental purposes of State Forests

\begin{tabular}{|l|l|l|}
\hline \multicolumn{1}{|c|}{ Economic purposes } & \multicolumn{1}{|c|}{ Social purposes } & \multicolumn{1}{|c|}{ Environmental purposes } \\
\hline Supply of wood and wood & Jobs creations & Protection of biodiversity \\
products & Tourism and recreation & Protection of soil and water \\
Supply of non-wood & Education & Protection of landscape \\
products & Forest products (e.g. mush- & Reduction of carbon dioxide \\
Supply of forest services & rooms, blueberry) & Regulation of water drainage \\
Production of medicines & & \\
\hline
\end{tabular}

Source: [Sadowska, 2016, p. 397].

Another principle governing the financial management of the SFNFH is the decentralisation of operations with the simultaneous centralisation of strategic decision-making. The organisational structure ${ }^{3}$ of the State Forests is largely hierarchical and there is a concentration of all the main functions within one unit which integrates forest management for most of the country [Brukas, Weber, 2009, pp. 589590]. This means that all key decisions are made by the General Directorate and assigned to the subordinate units. What is more, the financial interests of individual organisational units must be consistent with the interests of the SFNFH, which is the sole economic organisation [Buraczewski, 2013, pp. 247-248].

3 The organisational structure of the SFNFH comprises the General Directorate of the State Forests, 17 regional directorates of the State Forests (RDLP), 430 Forest Districts, and national and regional facilities. 


\section{Main elements of financial management of the State Forest}

The activity of the SFNFH and its organisational units is conducted on the basis of an economic balance consisting in measuring and comparing expenditures with the results, which is meant to provide management with information essential for making the most advantageous decisions [Sobiecki, 1997, p. 26]. Annual financial and economic plans containing information concerning objective tasks, revenues from sales, operational costs and financial results are all elements of this balance as well as the basis for financial management of the SFNFH.

The revenues of the State Forests are the sum of the revenues of individual organisational units which comprise that entity. These mainly include [Buraczewski, 2013, pp. 182-183]:

1. revenues from the sale of products, goods and materials or amounts due for their sale reduced by all applicable subsidies, discounts, rebates and exemptions, as well as VAT,

2. other operating revenues (including extraordinary gains) obtained from other operational activity covering, among other things, revenues from the sale by the State Forests of fixed assets or intangible assets, the embezzlement of timber,

3. revenues from financial operations covering due amounts from, e.g., the sale by the SFNFH of financial assets, as well as from dividends from held shares and stocks or interest from granted loans,

4. subsidies obtained from the state budget to realise tasks commissioned ${ }^{4}$ by the government which increase the of State Forests, ${ }^{5}$

5. subsidies from other sources, e.g., the National Fund for Environmental Protection and Water Management.

The costs of the SFNFH encompass financially measured and purposefully expanded production factors, including elements of fixed and current assets, external services and human labour incurred in connection with normal operation [Sojak, 2003, pp. 36-37]. One of the main characteristics of these costs is their purposefulness, which means that they are incurred in order to generate revenues. In regard to activity carried out by the State Forests, not all costs can be covered by generated revenues. This situation occurs with tasks associated with the realisation of nonproduction forest operations. The incurred costs are not always covered by revenues resulting from these activities or their value cannot be clearly determined because of accepted accounting standards [Ankudo-Jankowska, Glura, 2016, p. 164].

4 Targeted subsidies are used to realise such tasks as the carrying out of the national programme for increasing forestation, purchases of forests and land destined for new plantings and reclamation, updates on the state of forest assets and their inventorying, educating society about forests, or the protection and management of forests in cases where they are threatened [Maćkowiak, 2016, p. 118].

5 Equity capital of the SF is the equivalent to property of the State Treasury entrusted for management to individual organisational units [Act, 1994]. 
The main source of the State Forests' revenue is its general operations. Within this area, revenues are generated mainly through the sale of wood, seeds, cones, and seedlings. Meanwhile, costs are mainly incurred for carrying out core and administrative activities, chiefly for forest management (including seed production, selection, cultivation and planting of forests, and their protection), acquisition of wood (including felling, skidding, and hauling of wood), and the maintenance of Forestry Service [see: Public Information Bulletin of the SFNFH, 2017].

The financial result of the State Forests is the sum of the financial results of all its organisational units. It is calculated as the difference between the revenues generated by these units and their operational costs, with consideration for extraordinary gains and losses, which is subsequently reduced by any liabilities including, among others, income tax not covering administrative or core operations of the State Forests [Buraczewski, 2013, pp. 206-207]. Positive financial results of forest districts obtained within a given fiscal year are adjusted deducting the value of value of unfinished objective tasks from core activities and the portion of profit transferred to the General Directorate. The remaining part may be allocated to increase the equity (including the equity of the SF), additional bonuses, augmentation of the division's social benefits fund, or socially beneficial undertakings, but the combined value of assets allocated for the last three objectives cannot exceed $15 \%$ of generated profit [Act, 1994].

When analysing the financial management of the SFNFH, particular attention should be paid to the diverse natural conditions of individual forest districts which determine the level of the financial independence of these organisational units [Sadowska, 2015, p. 226]. The difference in the effects achieved as a result of their operations, as well as the obligation to observe the rule of self-financing by all the organisational units of the SFNFH, creates the need to compensate for financial inequality resulting from unfavourable natural and economic conditions existing in some forest districts [Buraczewski, 2001, p. 21]. To achieve this, pursuant to the Forests Act, a centralised financial system called the Forest Fund has been established [Sadowska, 2015, p. 227]. It is funded, among other sources, through:

1. general deductions of individual organisational units which debit the costs of their operations,

2. charges, penalties and payments made in connection with having to exclude forests from production,

3. funds received as part of various types of compensation,

4. income gained from shares and stocks of other companies, or from the sale of such assets,

5. budget subsidies with the exception of target subsidies for commissioned tasks.

Decisions regarding spending the funds from the Forest Fund are made by the General Director. The main aim of the Forest Fund is to redistribute resources earned by the State Forests in order to support deficient forest districts or establish comparable economic conditions for all the organisational units. Additionally, pursuant to Article 58 of the Forest Act [Act, 1991], these resources also fund, for 
example, scientific research, the realisation of shared undertakings, creation of essential infrastructure, drafting of forest management plans, protection of forest environments, or costs associated with work conducted on sites not belonging to the State Treasury, such as planting trees or clean-ups after natural disasters. Besides, the Forest Fund enables the financing of undertakings whose financial effects are only seen in the distant future and cannot be financed through long-term bank loans [Maćkowiak, 2016, pp. 119-220]. The General Director can also make the decision to apportion some resources from the Forest Fund to create a stabilising fund designed to finance activities related to removing extraordinary threats to forests as part of a long-term cycle of production.

The preparation, realisation, inventorying, analysis, and decision-making in regard to financial operations connected with productive investments or financial investments are yet another element of the SFNFH's financial management. Productive investments in the State Forests mainly concern the construction of a network of roads as well as other civil and water engineering structures and buildings. They are funded with external capital as well as from depreciation. Purchased or produced elements of assets as part of productive investments are recorded as tangible assets, while revenues and costs generated as a result of their realisation are mainly recorded as part of other operating revenues and expenses. The SFNFH also makes financial investments in the form of purchasing shares and stock of other enterprises. As a result of investing into financial assets, the SFNFH generates financial revenues and costs encompassing, for example, interest paid out or received through these assets [Maćkowiak, 2016, p. 121].

\section{Conclusions}

The presented analysis confirms that the financial management of the State Forests is influenced by numerous factors resulting from the unique character of their operations associated with forest management. On the one hand, there is a necessity to take into account the economic efficiency of conducted operations, as well as the need for maintaining the financial independence of all the SFNFH's organisational units. On the other hand, any initiated activities should comply with environmental requirements and the social needs of society. Management consistent with these conditions allows forests to perform their functions and fulfill the needs of current and future generations and, at the same time, to maintain the financial stability of the SFNFH.

\section{References}

Act of 28th September 1991 - Forest Act, Journal of Laws 1991, No. 101, Item 444. Act of 6th December 1994 - Rozporządzenie Rady Ministrów w sprawie szczegółowych zasad gospodarki finansowej w Państwowym Gospodarstwie Leśnym Lasy Państwowe, Journal of Laws 1994, No. 134, Item. 692. 
Agriculture, forestry and fishery statistics - 2017 edition, EUROSTAT (PDF), https://ec. europa.eu/eurostat/documents/3217494/8538823/KS-FK-17-001-EN-N.pdf/ c7957b31-be5c-4260-8f61-988b9c7f2316 [date of entry: 10.12.2017].

Ankudo-Jankowska A., Glura J., 2016, Ocena wykoraystania mierników ksiegowych do badania rentowności Państwowego Gospodarstwa Leśnego Lasy Państwowe, „Leśne Prace Badawcze", t. 77(2).

Brukas V., Weber N., 2009, Forest management after the economic transition - at the crossroads between German and Scandinavian tradition, "Forest Policy and Economics", no. 11.

Bugno-Pogoda A., Durak T., 2018, Zrównoważony rozwój w leśnictwie, „Polish Journal for Sustainable Development", vol. 22(1).

Buraczewski A. (ed.), 2013, Podstany rachunkowości i gospodarki finansowej w Lasach Państwowych, Wydawnictwo Uniwersytetu Przyrodniczego w Poznaniu, Poznań

Buraczewski A., 2001, Zarys organizacji $i$ zarzadzania w gospodarstwie leśnym, Wydawnictwo Akademii Rolniczej im. A. Cieszkowskiego w Poznaniu, Poznań.

Finanse przedsiebiorstwa, 2003, Szyszko L., Szczepański J. (red.), Polskie Wydawnictwo Ekonomiczne, Warszawa.

Gospodarka finansowa Lasów Państwowych, Supreme Audit Office (PDF), https://www. nik.gov.pl/plik/id,9302,vp,11524.pdf [date of entry: 19.12.2017].

Liubachyna A., Secco L., Pettenella D., 2017, Reporting practices of State Forest Enterprises in Europe, "Forest Policy and Economics", no. 78.

Local Data Bank, https://bdl.stat.gov.pl/BDL/dane/podgrup/tablica [date of entry: 15.12.2017].

Maćkowiak E., 2016, Finansowe podstany działalności Państwowych Gospodarstw Leśnych Lasy Państwowe, „Problemy Zarządzania”, t. 14, nr 4(63).

Misztal A., 2018, Zrównoważony rožoój polskich przedsięiorstw - ewaluacja „Handel Wewnętrzny", nr 2(373).

Płotkowski L., 2008, Ekonomiczne aspekty oceny funkciji lasu, csyli gospodarka leśna w koncepcji zrównoważonego rozwoju, „Studia i Materiały Centrum Edukacji PrzyrodniczoLeśnej”, r. 10, z. 3.

Public Information Bulletin, http://bip.lasy.gov.pl/pl/bip/finanse [date of entry: 11.01.2018].

Sadowska B., 2015, Rachunkowość w Państwouym Gospodarstwie Leśnym Lasy Państwowe, „Prace Naukowe Uniwersytetu Ekonomicznego we Wrocławiu”, nr 390.

Sadowska B., 2016, Strategia Państwowego Gospodarstwa Lénnego Lasy Państwowe a zrónnoważony rožój;, „Prace Naukowe Uniwersytetu Ekonomicznego we Wrocławiu”, nr 437.

Sadowska B., Lulek, A., 2018, The problem of risk in the economy of sustainable development on the example of the State Forests, „Ekonomia i Prawo”, vol. 17(1).

Sobiecki R., 1997, Zarys gospodarki rynkowej, Wydawnictwo Euromark, Warszawa.

Sojak S., 2003, Racbunkowość zarzadcza, Wydawnictwo Dom Organizatora, Toruń.

Szczypa P., 2016, Istota i rodzaje pożqdanych zmian w rachunkowości Lasów Państwonych, „Zeszyty Naukowe Uniwersytetu Ekonomicznego w Katowicach”, nr 300.

Szewczuk A., 2006, Dylematy gospodarki finansowej w polskim sektorze samorzadonym na tle akcesji do Unii Europejskiej, „Acta Universitatis Lodziensis. Folia Oeconomica”, nr 197. 